\title{
Phytotoxic Activity of Oil Palm Frond Mulch in Combination with Selected Pre- Emergence Herbicide
}

(Aktiviti Fitotoksik Sungkupan Pelepah Kelapa Sawit dalam Gabungan dengan Herbisid Pracambah Terpilih)

\author{
Dilipkumar Masilamany, Muhammad Amirul Nordin, Norhafizah Md Zain, Ismail Bin Sahid \& ChuaH \\ TSE SENG*
}

\section{ABSTRACT}

The combination of mulch and herbicide is a promising method for weed control which could reduce the frequency of hand weeding. This study was conducted to evaluate the phytotoxic effects of Elaeis guneensis var. tenera (oil palm) frond (OPF) mulch in combination with several pre emergence herbicides on the inhibition of goosegrass (Eleusine indica (L.) Gaertn), slender cyperus (Cyperus distans L.f.) and coat buttons (Tridax procumbens (L.)) under greenhouse conditions. Three rates of dinoterb, oxyfluorfen, and isoxaflutole were respectively, applied with or without OPF

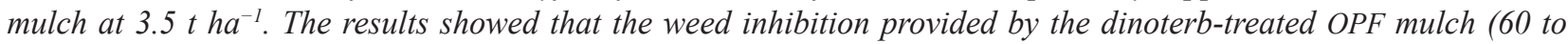
$100 \%$ ) was greater than dinoterb (0 to 50\%) or OPF mulch (0 to 60\%) applied alone across all the application rates and bioassay species. The oxyfluorfen-treated OPF mulch also gave greater inhibition (70 to 90\%) of T. procumbens than those provided by oxyfluorfen (20 to 40\%) or the OPF mulch alone (55 to 60\%). However, an increase in inhibition of $\mathrm{C}$. distans and $\mathrm{E}$. indica was only evident at a low rate of oxyfluorfen when combined the OPF mulch. Weed inhibition was noted with increasing rates of isoxaflutole alone but the isoxaflutole-treated OPF mulch did not lead to further inhibition of weeds except for $\mathrm{T}$. procumbens. These results suggest that the phytotoxicity of OPF mulch in combination with herbicides are dependent on weed species, herbicides, and application rates, with dinoterb being the most compatible with OPF mulch when combined.

Keywords: Elaesis guneensis var. tenera; oil palm frond; rachis; residue mulch; seedling emergence; seedling growth

\section{ABSTRAK}

Gabungan antara sungkupan dan herbisid adalah kaedah yang berpotensi untuk mengawal rumpai kerana ia boleh mengurangkan kekerapan merumpai menggunakan tangan. Kajian ini dijalankan untuk menilai kesan fitotoksik sungkupan pelepah Elaeis guneensis var. tenera (kelapa sawit), OPF dengan gabungan beberapa herbisid pracambah ke atas perencatan rumput sambau (Eleusine indica (L.) Gaertn), slender cyperus (Cyperus distans L.f.) dan rumpai kancing baju (Tridax procumbens (L.)) di bawah keadaan rumah hijau. Tiga kadar dinoterb, oksifluorfen dan isoksaflutol, masing-masing diaplikasikan dengan atau tanpa sungkupan OPF pada 3.5 t ha ${ }^{-1}$. Keputusan menunjukkan bahawa perencatan rumpai yang diberi sungkupan OPF terawat dinoterb (60 hingga 100\%) lebih besar berbanding dinoterb (0 hingga 50\%) atau sungkupan OPF (0 hingga 60\%) sahaja untuk semua kadar aplikasi dan spesies bioasai. Sungkupan OPF terawat oksifluorfen juga memberikan perencatan yang besar (70 hingga 90\%) ke atas T. procumbens berbanding oksifluorfen (20 hingga 40\%) atau sungkupan OPF sahaja (55 hingga 60\%). Walau bagaimanapun, peningkatan perencatan ke atas C. distans dan E. indica hanya ketara pada kadar oksifluorfen yang rendah apabila digabungkan dengan sungkupan OPF. Perencatan rumpai dapat dilihat dengan peningkatan kadar isoksaflutol sahaja tetapi sungkupan OPF terawat isoksaflutol tidak membawa kepada perencatan rumpai kecuali untuk T. procumbens. Keputusan ini mencadangkan bahawa kefitotoksikan sungkupan OPF dengan gabungan herbisid bergantung kepada spesies rumpai, herbisid, dan kadar aplikasi, dengan dinoterb paling sesuai digabungkan dengan sungkupan OPF.

Kata kunci: Elaesis guneensis var. tenera; kemunculan anak benih; pelepah kelapa sawit; pertumbuhan anak benih; rakis; sisa sungkupan

\section{INTRODUCTION}

Organic mulch is one of the most common method for weed control in landscape planting beds. It can reduce water loses through evapotranspiration and conserve moisture as well as nutrient, reduce soil degradation, nourish rhizosphere biota, and reduce farm inputs and greenhouse gases emissions (Malhi \& Lemke 2007; Sharma et al. 2011). Typically, organic mulch is derived from plant 
materials, such as hardwood and softwood bark, rice hulls, lawn clippings, pine needles, sawdust, straw, and wood chips (Somireddy 2012). Oil palm (Elaesis guneensis var. tenera) fronds (OPFs) are commonly used for mulching in oil palm cultivation (Khalid et al. 1999). Pruned OPFs are available all year, and whole fronds are placed around the base of oil palm trees to improve fertility and reduce soil erosion (Dilipkumar et al. 2017a; Moraidi et al. 2012). Dilipkumar et al. (2015) showed that OPF mulch is better than the residual mulch of pineapple and coconut in inhibiting goosegrass (Eleusine indica (L.) Gaertn) emergence and growth. Moreover, OPF rachis extracts prevent $E$. indica seed germination at concentrations as low as $1.0 \%(\mathrm{w} / \mathrm{v})$ (Chuah \& Lim 2015). The OPF mulch containing 21\% lignin and 33\% hemicellulose (Lai et al. 2016) as well as have high level of allelochemicals such as flavonoids which act additively or synergistically with preemergence herbicide, imazethapyr (Dilipkumar et al. 2015, 2019; Muhammad Amirul et al. 2019).

Preemergence herbicide is utilized as a part of weed control strategy in nursery and landscapes. There are few preemergence herbicides used widely in landscapes, namely pendimethalin, prodiamine, oxyfluorfen, s-metolachlor, dichlobenil, isoxaben, and indaziflam (Senseman 2007). However, no single herbicide can control a wide range of weeds. Prepackaged blends of herbicides or tank-blending individual broadleaf herbicide with graminicide are a typical practice to accomplish wide range weed control (Altland et al. 2003; Judge et al. 2003). For instance, new granular herbicide premixes, such as oxadiazon plus prodiamine and oxyfluorfen plus oxadiazon, are becoming increasingly popular for their broad spectrum weed control in nurseries and landscapes (Somireddy 2012).

Many factors could affect performance of preemergence herbicide. Adsorption, leaching, and volatilization are the physical processes that occur to preemergence herbicides in the soil. Herbicide losses are regularly higher for fluid formulation as compared to granular formulation (Mahnken et al. 1992). For example, emulsifiable concentrations can make the herbicides more inclined to losses by runoff or leaching (Gorski 1993). Herbicides that quickly discharge active ingredients can likewise reduce the time of weed control compared to slow-release formulations (Sopena et al. 2009). These worries specified demonstrate a reasonable requirement for new herbicide application strategies that decrease off target herbicide movement.

In the landscape management and maintenance, applying herbicides above or below the mulch and incorporated in the mulch, commonly provides long-term and broad-spectrum weed control (Case \& Mathers 2006; Marble 2015). Nevertheless, herbicides behave differently when applied to different organic materials (Case et al.

TABLE 1. Chemical and physical properties of dinoterb, oxyfluorfen and isoxaflutole

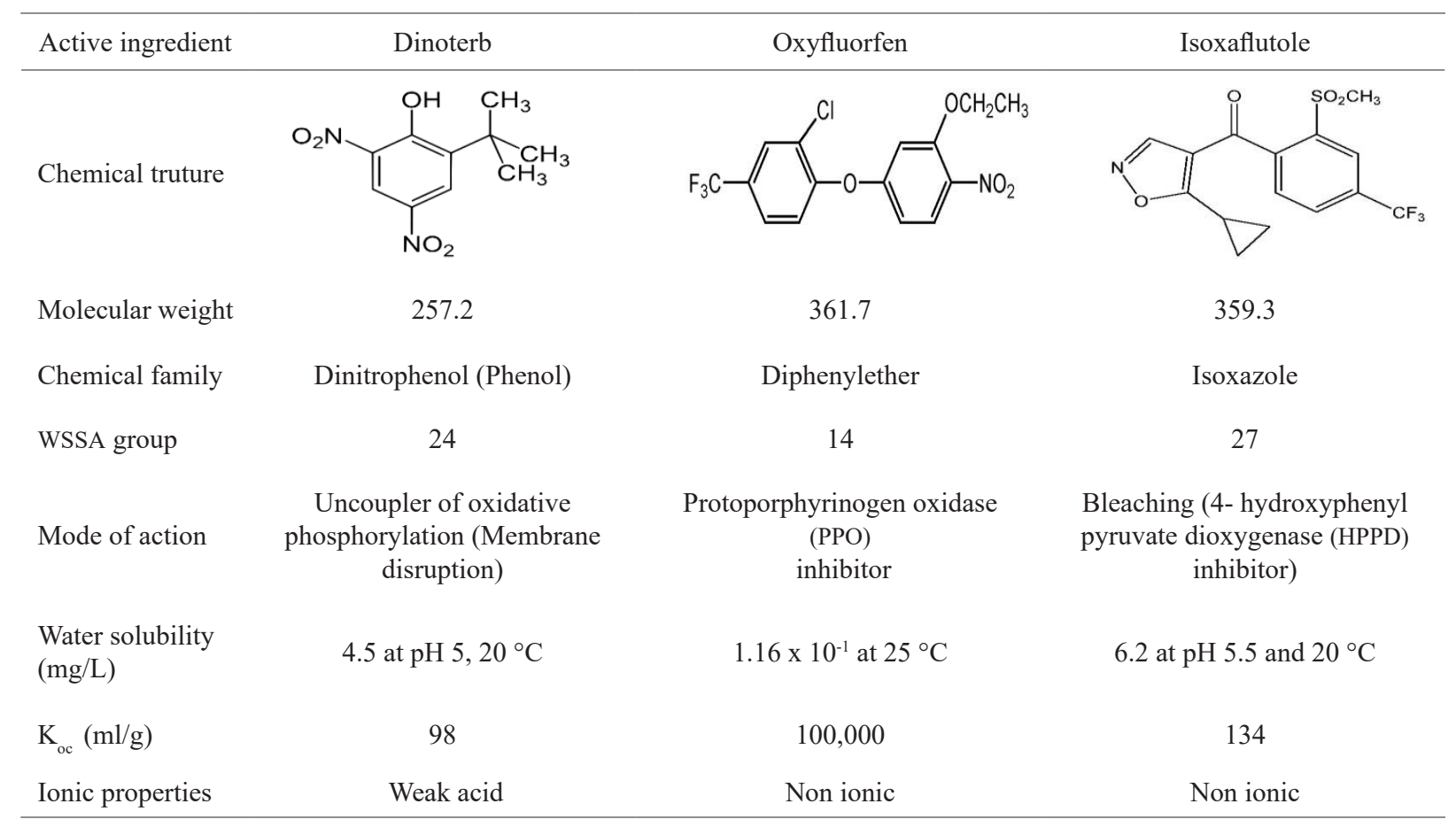

(Martins \& Mermoud 1998; Plimmer et al. 2002; Shaner 2014; Taylor et al. 2000) 
2002; Marble 2015; Mathers 2003; Mathers \& Case 2010). For instance, interactions between organic mulch and herbicides have produced mixed results ranging from no interaction (Chen et al. 2013), antagonism (Chauhan \& Abugho 2012), or synergism (Case \& Mathers 2006; Mathers \& Case 2010) depending on the placement, type, and rate of herbicides and plant residues used. Chen et al. (2013) reported that the application of EPTC above pine mulch provided $70 \%$ control of yellow nutsedge (Cyperus esculentus L.), however, when EPTC applied beneath the mulch exhibited $85 \%$ reduction in C. esculentus. Conversely, flumioxazin-treated hardwood mulch exhibited greater efficacy on weed and reduce phytotoxicity on crop compared to those treated with mulch or flumioxazin alone (Case \& Mathers 2006). According to Chauhan and Abugho (2012), pendimethalin application at $1 \mathrm{~kg}$ $\mathrm{ha}^{-1}$ resulted in lower barnyard grass (Echinochloa crusgalli (L.) P. Beauv.) control in the presence of $6 \mathrm{tha}^{-1}$ rice residue relative to the same application in the absence of residue. Information is scarce with regard to the phytotoxic effects of OPF mulch combined with dinoterb, oxyfluorfen, or isoxaflutole for weed inhibition in landscapes and nurseries. Pre-emergence herbicides are studied in the current research because of their distinct chemical and physical properties (Table 1) that are thought to change their inhibitory effect when combined with residual OPF mulch. The objectives of this study were: to evaluate the effects of residual OPF mulch applied alone on the seedling emergence and growth of selected weeds in landscapes and nurseries; goosegrass (Eleusine indica (L.) Gaertn), slender cyperus (Cyperus distans L.f.) and coat buttons [Tridax procumbens (L.)]; and to assess the inhibitory effects of dinoterb, oxyfluorfen, and isoxaflutole on several common weeds following three herbicide rates applied with or without residual OPF mulch.

\section{MATERIALs AND Methods}

\section{PLANT MATERIALS}

Seeds of common weed species found in landscapes, including goosegrass (Eleusine indica (L.) Gaertn), slender cyperus (Cyperus distans L.f.) and coat buttons (Tridax procumbens (L.)) represented grassy weed, sedge, and broadleaf weed, respectively, were collected from Bukit Kor, Marang, Terengganu, Malaysia $\left(5^{\circ} 22^{\prime} \mathrm{N}, 103^{\circ} 18^{\prime}\right.$ E). Eleusine indica seeds were scarified with sandpaper to encourage germination (Ismail et al. 2002). Seeds of each species were soaked in $0.2 \%$ potassium nitrate solution for $24 \mathrm{~h}$ to break dormancy prior being used. A preliminary viability test was conducted, and the results confirmed that germination rates $>90 \%$. Fresh OPFs were collected from 35-year-old trees near MARDI, Seberang Prai, Pulau Pinang, Malaysia $\left(5^{\circ} 54^{\prime} \mathrm{N}, 100^{\circ} 47^{\prime} \mathrm{E}\right)$. OPFs were initially cut into small pieces with lengths ranging from $6 \mathrm{~cm}$ to $10 \mathrm{~cm}$ using a chopper machine (DISK MILL FFC-23, Shandong JimoHairong Machinery Co. Ltd.) and then sun-dried in a greenhouse for a month. After complete drying, the OPF pieces were ground to powder using the same mill $(<2 \mathrm{~mm}$ particle size $)$ and stored at $4{ }^{\circ} \mathrm{C}$ prior to use.

\section{GREENHOUSE EXPERIMENTS}

Experiments were conducted in the greenhouse with 12 $\mathrm{h}$ photoperiods. Temperature and light intensities ranged from 29 to $32^{\circ} \mathrm{C}$ and 800 to $1200 \mu \mathrm{Em}^{-2} \mathrm{~s}^{-1}$, respectively. Greenhouse was located at the School of Food Science and Technology, Universiti Malaysia Terengganu, Terengganu, Malaysia $\left(5.24^{\circ} \mathrm{N}, 103.05^{\circ} \mathrm{E}\right)$.

A total of $150 \mathrm{~g}$ of sandy clay soil (44\% clay, $10 \%$ silt, and $46 \%$ sand; $\mathrm{pH} 4.3 ; 1.7 \%$ organic matter; $0.5 \%$ nitrogen $(\mathrm{N}) ; 1.7 \mathrm{mg} / \mathrm{kg}$ phosphorus $(\mathrm{P}) ; 102.1 \mathrm{mg} /$ $\mathrm{kg}$ potassium (K) $\mathrm{mg} / \mathrm{kg}$; and $2.2 \mathrm{meq} / 100 \mathrm{~g} \mathrm{CEC}$ ) was mixed with $0.22 \mathrm{~g}$ of dry chicken dung $(1.5 \% \mathrm{~N}, 0.4 \%$ $\mathrm{P}$, and $0.8 \%$ potassium) and placed in a paper cup $(7 \mathrm{~cm}$ diameter $\times 9 \mathrm{~cm}$ height) with six holes at the bottom for drainage. Each cup was placed in a $50 \times 100 \mathrm{~cm}$ tray, and water was applied to the tray to allow the capillary uptake of water from the bottom of the cup. Water was removed from the tray when the soil surface appeared moist. Ten seeds of $E$. indica, $C$. distans, or $T$. procumbens were sown on the soil surface in the cups and then placed in the greenhouse. Analytical standard of dinoterb, oxyfluorfen, and isoxaflutole were used to treat the OPF mulch powder to eliminate confounding factor due to adjuvant of commercial grade of herbicide. A preliminary doseresponse test was carried out to determine three herbicide rates that resulted in 0 to $90 \%$ of weed inhibition. Dinoterb was applied at $0,0.38,1.5$, and $6 \mathrm{~g}$ a.i ha ${ }^{-1}$; oxyfluorfen at $0,0.12,0.49$, and $1.95 \mathrm{~g} \mathrm{a.i} \mathrm{ha}^{-1}$; and isoxaflutole at 0 , $0.16,0.33$, and $0.65 \mathrm{~g}$ a.i ha ${ }^{-1}$ with or without OPF mulch at $3.5 \mathrm{t} \mathrm{ha}^{-1}$.

The OPF mulch preparation and application rate were followed as described by Dilipkumar et al. (2015). Each herbicide (active ingredient) was dissolved in $5 \mathrm{~mL}$ of acetone and pipetted into a $9 \mathrm{~cm}$ Petri dish containing $1.56 \mathrm{~g}$ of sieved soil $(2 \mathrm{~mm})$ or $1.56 \mathrm{~g}$ of residual OPF powders at room temperature. An additional 4 and $8 \mathrm{~mL}$ of acetone were poured into the soil and OPF mulch powder, respectively, to create a uniform distribution of each herbicide. Each Petri dish was sealed and gently shaken to allow the thorough incorporation of the solution into the soil or OPF mulch powder. The Petri dishes were then placed in a fume hood for $24 \mathrm{~h}$ prior to application into the paper cup. Irrigation with $10 \mathrm{~mL}$ of water applied to the top of each cup was performed daily. At three weeks after treatment (WAT), the $\mathrm{pH}$ of the soil treated with OPF alone was measured, seedling emergence rate (SER) was recorded on the basis of the number of seeds with emerged shoots, and above-ground plant tissue was harvested and oven dried at $60{ }^{\circ} \mathrm{C}$ for two weeks to obtain the shoot dry weight (SDW). The seedlings were considered emerged when the plumule lengths were $>2 \mathrm{~mm}$. Cups with seeded but untreated soil (without herbicide and OPF mulch) served as controls. The data were expressed as percentages of their respective controls. 


$$
\begin{aligned}
& \mathrm{SER}=(\mathrm{ET} / \mathrm{EC}) \times 100 \% \\
& \mathrm{SDW}=(\mathrm{SDT} / \mathrm{SDC}) \times 100 \%
\end{aligned}
$$

where ET is number of seeds with emerged shoots in treatment (mulch alone, herbicide alone or herbicidetreated mulch); EC is number of seeds with emerged shoots in untreated soil (without OPF mulch and herbicide); SDT is SDW in treatment; and SDC is SDW in untreated soil.

\section{EXPERIMENTAL DESIGN AND STATISTICAL ANALYSIS}

The experiment was arranged in a completely randomized design with three replications and then repeated twice in time. Weed emergence and shoot biomass percentages of each species were checked for homogeneity of variance. In some circumstances, data were transformed to improve variance homogeneity. For example, an arcsine square root transformation was performed on the percent data for $E$. indica seedling emergence treated with isoxaflutole. Square root $(\mathrm{x}+1)$ transformation was conducted for the seedling biomass of the T. procumbens treated with dinoterb. The data were then subjected to a two-way ANOVA where factor 1 is herbicide rate ( 3 different rates) while factor 2 is presence of OPF mulch (with or without). Data were combined because of no effect of time. The means were compared using Tukey's honestly significant difference test at a 5\% significance level.

\section{RESULTS AND DISCUSSION}

The application of oil palm frond (OPF) mulch alone at $3.5 \mathrm{t} \mathrm{ha}^{-1}$ inhibited the E. indica and T. procumbens seedling emergence by 20 and $58 \%$, respectively, and had no significant effect on $C$. distans (Table 2), implying that the efficacy of residual OPF powder on inhibiting seedling emergence is species dependent with $C$. distans being the least sensitive and $T$. procumbens the most sensitive. However, shoot growth of the weeds was inhibited approximately by $60 \%$ regardless of any weed species (Table 2). In general, there was a significant interaction between application of herbicide and the presence of mulch on weed seedling emergence and weed growth inhibition except for $T$. procumbens treated with oxyfluorfen (Figures 1, $2 \& 3$ ).

TABLE 2. Inhibitory effect of oil palm frond (OPF) powder alone at $3.5 \mathrm{t} \mathrm{ha}^{-1}$ on Eleusine indica, Cyperus distans and Tridax procumbens three weeks after treatment

\begin{tabular}{lcc}
\hline Weed species & $\begin{array}{c}\text { Seedling emergence } \\
\text { (\% of control) }\end{array}$ & Shoot dry weight \\
\hline Eleusine indica & 20 & 60 \\
Cyperus distans & 99 & 50 \\
Tridax procumbens & 58 & 59 \\
\hline
\end{tabular}

*Untreated soil (without herbicide and OPF) is served as control

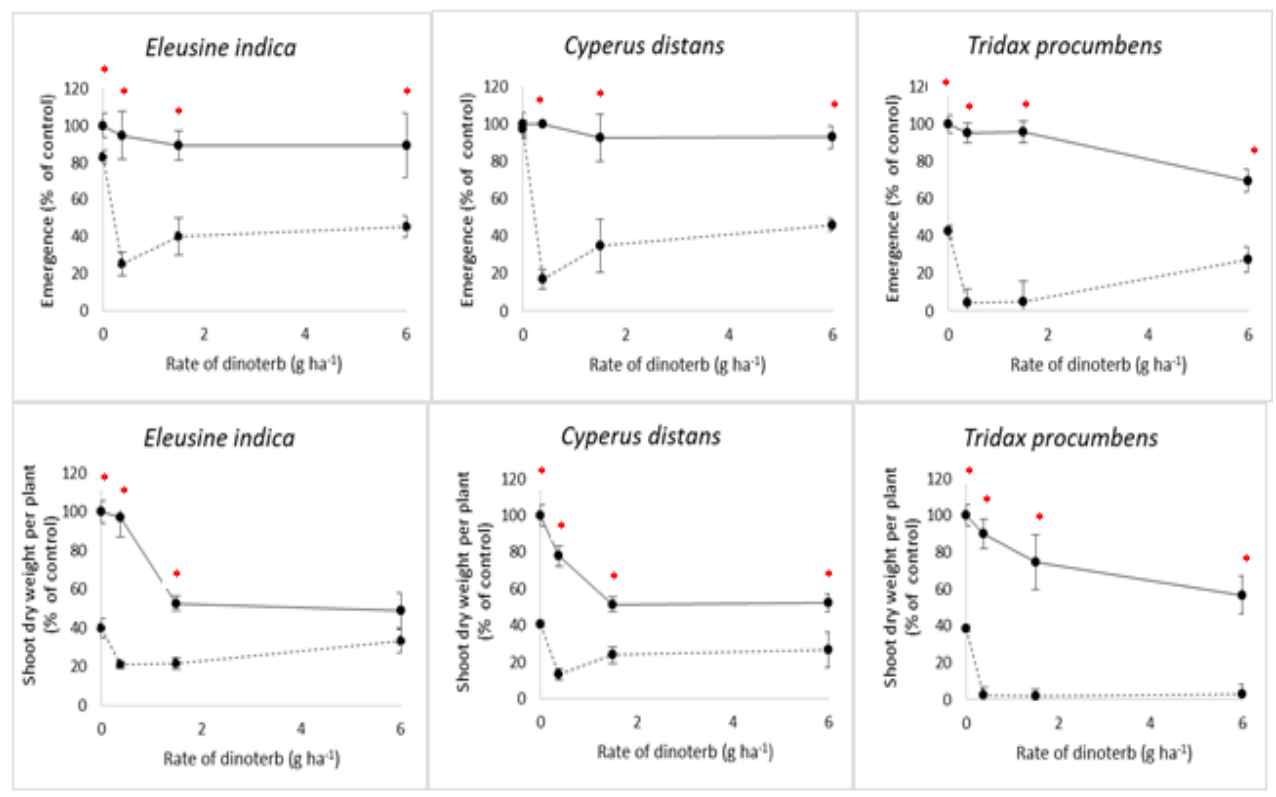

FIGURE 1. Inhibitory effect of dinoterb (-) and dinoterb-treated oil palm frond residue mulch (- -) on seedling emergence and growth of Eleusine indica, Cyperus distans and Tridax procumbens three weeks after treatment. The untreated soil (without herbicide and OPF mulch) is served as control.

$*$ denotes significant difference between herbicide alone and herbicide + mulch within the same herbicide rate at $5 \%$ of significant level 
PHYTOTOXICITY OF OPF MULCH COMBINED WITH DINOTERB

Dinoterb alone failed to effectively inhibit seedling emergence of each bioassay species irrespective of any application rate (Figure 1). In contrast, the weed growth was inhibited by 5 to $50 \%$ with increasing rates of dinoterb applied alone, indicating that dinoterb acts a shoot inhibitor rather than germination inhibitor. Interestingly, the inhibition of weed emergence and growth were significantly increased by 60 to $100 \%$ by the dinoterb-treated OPF, but the herbicide rates greater than $0.38 \mathrm{~g} \mathrm{ha}^{-1}$ appeared to be unnecessary for adequate control of weed species when combined with the OPF mulch. Weak acid herbicides, such as dinoterb, tended to absorb soil particles because its pKa (4.8) value (Escher $\&$ Schwarzenbach 2000) is close to the soil $\mathrm{pH}$ value (4.3) of the present study, thereby leading to low inhibition of weed emergence when applied alone. It has been shown that wheat (Triticum aestivum L.) straw temporarily increased the soil pH (Schmitz et al. 2001). Likewise, the OPF mulch could increase the soil $\mathrm{pH}$ from 4.3 to 6.0 in the present study. Dinoterb has a predominantly negative charge (Kah \& Brown 2006) when the soil pH is close to 7 , thus leading to free dinoterb molecules available for root uptake with greater inhibition of weed. Nevertheless, the leaching potential of dinoterb is likely to be high due to its low Koc of $98 \mathrm{mLg}^{-1}$ (Martins \& Mermoud 1998) with a water solubility of $4.5 \mathrm{mgL}^{-1}$ (Shaner 2014) but dinoterb leaching could be reduced because the OPF mulch may act as a slow release carrier of dinoterb as reported by Dilipkumar et al. (2017b) when the OFF mulch was combined with weak acid herbicide like imazethapyr.

\section{PHYTOTOXICITY OF OPF MULCH COMBINED WITH OXYFLUORFEN}

Seedling emergence of weeds was inhibited with increasing rates of oxyfluorfen applied alone (Figure 2). Oxyfluorfen at the lowest rate of $0.12 \mathrm{~g} \mathrm{ha}^{-1}$ resulted in approximately $60 \%$ inhibition of weed growth. However, the suppression of weed growth by oxyfluorfen was significantly increased to $90 \%$ at $0.12 \mathrm{~g} \mathrm{ha}^{-1}$ with the presence of OPF mulch. Oxyfluorfen has high Koc of $100,000 \mathrm{mgL}^{-1}$ and low water solubility of $0.12 \mathrm{mgL}^{-1}$ (Alister et al. 2009; Shaner 2014) which cause the herbicide is strongly adsorbed by soil organic matter. As a result, few oxyfluorfen molecules are free for root uptake, thereby leading to moderate inhibition of weed growth when applied alone at $0.12 \mathrm{~g} \mathrm{ha}^{-1}$. However, the OPF mulch may act as a slow release carrier of oxyfluorfen at $0.12 \mathrm{~g} \mathrm{ha}^{-1}$ and caused further significant increase in weed growth inhibition. Tridax procumbens was more tolerant than $E$. indica and $C$. distans when treated with oxyfluorfen alone, suggesting that herbicidal activity of oxyfluorfen is selective. Interestingly, the herbicide selectivity on $T$. procumbens could be overcome after combined with the OPF mulch. However, there was no benefit of increasing the rate of oxyfluorfen over $0.12 \mathrm{~g} \mathrm{ha}^{-1}$ in combination with the OPF mulch on seedling emergence and growth of all tested weeds. This result indicates that compatibility of the OPF mulch with oxyfluorfen is influenced by herbicide rate and bioassay species.

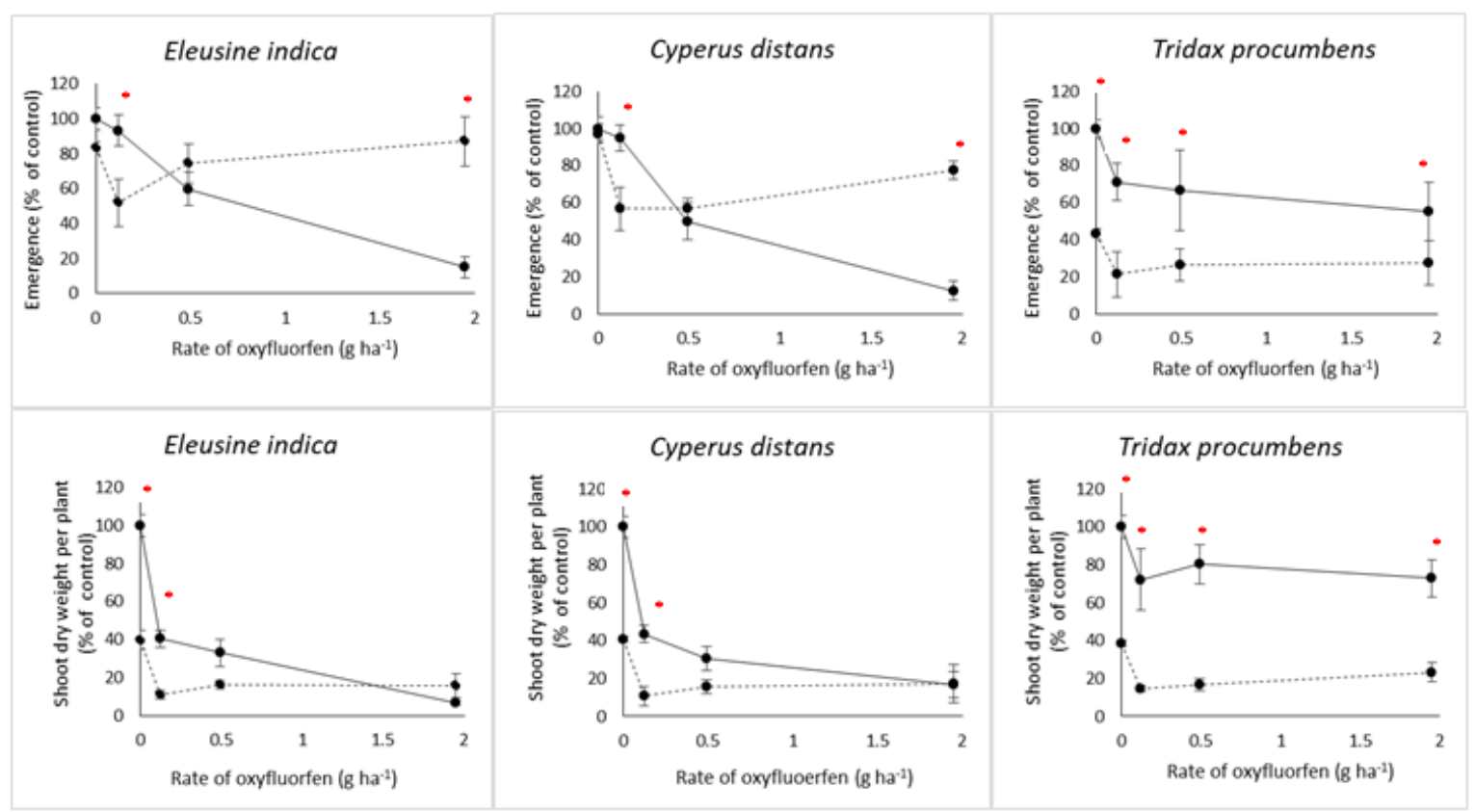

FIGURE 2. Inhibitory effect of oxyfluorfen $(-)$ and oxyfluorfen-treated oil palm frond residue mulch

(- -) on seedling emergence and growth of Eleusine indica, Cyperus distans and Tridax procumbens three weeks after treatment. The untreated soil (without herbicide and OPF mulch) is served as control. * denotes significant difference between herbicide alone and herbicide + mulch within the same herbicide rate at $5 \%$ of significant level 


\section{PHYTOTOXICITY OF OPF MULCH COMBINED WITH ISOXAFLUTOLE}

Weed seedling emergence was inhibited with increasing rates of isoxaflutole applied alone (Figure 3 ). Isoxaflutole applied alone at 0.33 and $0.65 \mathrm{~g} \mathrm{ha}^{-1}$ significantly reduced the seedling emergence of $C$. distans by up to $90 \%$, but the inhibition of emergence was reduced to $40 \%$ when subjected to the isoxaflutole-treated OPF. In contrast, significant reduction in the emergence of T. procumbens was noted when treated with the pretreated OPF as compared to isoxaflutole alone across all application rates (Figure 3). Weed shoot growth was inhibited with increased rates of isoxaflutole alone. Interestingly, the isoxaflutole-treated OPF provided greater reduction of $T$. procumbens growth, whereas there were no significant differences on $E$. indica and $C$. distans which were almost similar to isoxaflutole alone at the rate of isoxaflutole over $0.16 \mathrm{~g} \mathrm{ha}^{-1}$. There was no benefit of increasing the rate of isoxaflutole over $0.16 \mathrm{~g} \mathrm{ha}^{-1}$ in combination with the OPF mulch on seedling emergence and growth of weeds. In addition, these results also imply that the OPF mulch is not a good carrier for slow release of isoxaflutole probably due to its lack of stability and natural hydrolysis to its diketonitrile (DKN) derivative (Pallet et al. 2001), which tends to leach more than isoxaflutole does (Alletto et al. 2012) as a result of a low Koc value $\left(17 \mathrm{gmL}^{-1}\right)$ and the high value of water solubility $\left(326 \mathrm{gmL}^{-1}\right)$.

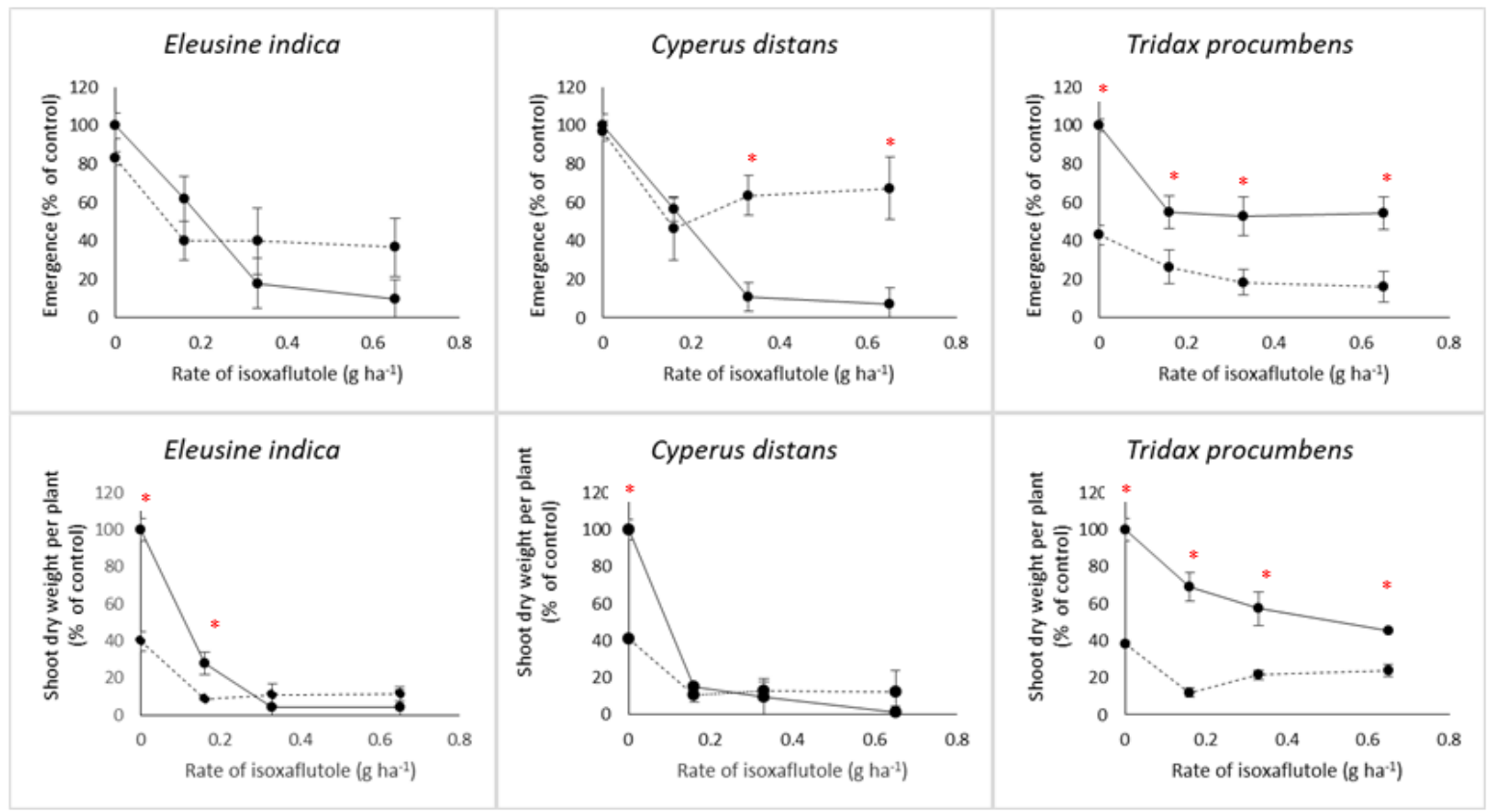

FIGURE 3. Inhibitory effect of isoxaflutole $(-)$ and isoxaflutole-treated oil palm frond residue mulch (- -) on seedling emergence and growth of Eleusine indica, Cyperus distans and Tridax procumbens three weeks after treatment. The untreated soil (without herbicide and OPF mulch) is served as control. $(*$ denotes significant difference between herbicide alone and herbicide + mulch within the same herbicide rate at $5 \%$ of significant level)

\section{CONCLUSION}

In summary, the emergence and seedling growth of weeds were suppressed greatly when subjected to OPF mulch treated with dinoterb regardless of the application rate and bioassay species, suggesting high compatibility between dinoterb and the OPF mulch. Interactions between OPF mulch and oxyfluorfen or isoxaflutole were rate and species dependent. Differential interactions between preemergence herbicides and OPF mulch are most likely related to herbicide selectivity to weed, the chemical and physical properties of herbicides.

\section{ACKNOWLEDGEMENTS}

Financial support was provided by the Ministry of Agriculture and Agro-Based Industry, Malaysia - MARDI (PRI-198). No conflicts of interest have been declared. 


\section{REFERENCES}

Alister, C.A., Gomez, P.A., Rojas, S. \& Kogan, M. 2009. Pendimethalin and oxyfluorfen degradation under two irrigation conditions over four years application. Journal of Environmental Science and Health, Part B 44(4): 337-343.

Alletto, L., Benoit, P., Bergheaud, V. \& Coquet, Y. 2012. Variability of retention process of isoxaflutole and its diketonitrile metabolite in soil under conventional and conservation tillage. Pest Management Science 68(4): 610617.

Altland, J.E., Gilliam, C.H. \& Wehtje, G.W. 2003. Weed control in field nurseries. HortTechnology 13(1): 9-14.

Case, L.T. \& Mathers, H.M. 2006. Herbicide-treated mulches for weed control in nursery container crops. Journal of Environmental Horticulture 24(2): 84-90.

Case, L., Mathers, H.M. \& Tuttle, N. 2002. Herbicide-treated mulches for ornamental weed control. Proceeding of the Northeastern Weed Science Society 56: 72.

Chauhan, B.S. \& Abugho, S.B. 2012. Interaction of rice residue and pre herbicides on emergence and biomass of four weed species. Weed Technology 26(4): 627-632.

Chen, Y., Strahan, R.E. \& Bracy, R.P. 2013. Effects of mulching and preemergence herbicide placement on yellow nutsedge control and ornamental plant quality in landscape beds. HortTechnology 23(5): 651-658.

Chuah, T.S. \& Lim, W.K. 2015. Assessment of phytotoxic potential of oil palm leaflet, rachis and frond extracts and powders on goosegrass (Eleusine indica (L.) Gaertn.) germination, emergence and seedling growth. Malaysian Applied Biology Journal 44(2): 75-84.

Dilipkumar, M., Muhammad Amirul, N., Ismail, S. \& Chuah, T.S. 2019. Effects of imazethapyr treated oil palm frond residue mulch on weed control and ornamental plant quality in nurseries. Indian Journal of Horticulture 76(1): 148-154.

Dilipkumar, M., Chuah, T.S., Goh, S.S. \& Ismail, S. 2017 a. Weed management issues, challenges, and opportunities in Malaysia. Crop Protection 134: 1-9.

Dilipkumar, M., Mazira, C.M. \& Chuah, T.S. 2017b. The potential use of oil palm frond mulch treated with imazethapyr for weed control in Malaysian coconut plantation. Sains Malaysiana 46(8): 1171-1181.

Dilipkumar, M., Mazira, C.M. \& Chuah, T.S. 2015. Phytotoxicity of different organic mulches on emergence and seedling growth of goosegrass (Eleusine indica). Journal of Tropical Agriculture and Food Science 43(2): 145-153.

Escher, B.I. \& Schwarzenbach, R.P. 2000. Evaluation of liposome - water partitioning of organic acids and bases. Environmental Science \& Technology 34(18): 3954-3961.

Gorski, S.F. 1993. Slow-release delivery system for herbicides in container-grown stock. Weed Technology 7(4): 894-899.

Ismail, B.S., Chuah, T.S., Salmijah, S., Teng, Y.T. \& Schumacher, R.W. 2002. Germination and seedling emergence of glyphosate-resistant and susceptible biotypes of goosegrass (Eleusine indica (L.) Gaertn.). Weed Biology and Management 2(4): 177-185.

Judge, C.A., Neal, J.C. \& Leidy, R.B. 2003. Trifluralin (Preen) dissipation from the surface layer of a soilless plant growth substrate. Journal of Environmental Horticulture 21(4): 216-222.
Kah, M. \& Brown, C.D. 2006. Adsorption of ionisable pesticides in soils. Reviews of Environmental Contamination and Toxicology 188: 149-217.

Khalid, H., Zin, Z.Z. \& Anderson, J.M. 1999. Effect of oil palm residues management at replanting on soil nutrient dynamics and oil palm growth. In Proceeding of the PORIM International Palm Oil Congress. Kuala Lumpur, Malaysia: Malaysian Palm Oil Board. pp. 235-246.

Lai, L.W., Marini, I., Nasrudin, M.R., Hashim, E.F., Ya'cob, M.Z., Ani, I. \& Junaid, A. 2016. Study on composition, structural and property changes of oil palm frond biomass under different pretreatments. Cellulose Chemistry and Technology 50(9-10): 951-959.

Mahnken, G.E., Skroch, W.A. \& Sheets, T.J. 1992. Loss of simazine and metolachlor in surface runoff water from a container ornamental production site. In Weed Science Society of America Abstracts. Champaign, IL: Weed Science Society of America. p. 111.

Malhi, S. \& Lemke, R.L. 2007. Tillage, crop residue and N fertilizer effects on crop yield, nutrient uptake, soil quality and nitrous oxide gas emissions in a second 4-yr rotation cycle. Soil \& Tillage Research 96(1-2): 269-283.

Marble, S.C. 2015. Herbicide and mulch interactions: a review of the literature and implications for the landscape maintenance industry. Weed Technology 29(3): 341-349.

Martins, J.M. \& Mermoud, A. 1998. Sorption and degradation of four nitroaromatic herbicides in mono and multi-solute saturated/unsaturated soil batch systems. Journal of Contaminant Hydrology 33(1-2): 187-210.

Mathers, H. 2003. Novel methods of weed control in containers. HortTechnology 13(1): 28-31.

Mathers, H. \& Case, L.T. 2010. Microencapsulated herbicidetreated bark mulches for nursery container weed control. Weed Technology 24(4): 529-534.

Moraidi, A., Teh, C.B.S., Goh, K.J., Husn, A.M.H. \& Fauziah, I. 2012. Evaluation of four soil conservation practices in a non-terraced oil palm plantation. Agronomy Journal 104(6): 1727-1740.

Muhammad Amirul, N., Dilipkumar, M. \& Chuah, T.S. 2019. Different imazethapyr placements and rainfall amounts affect phytotoxic activity of imazethapyr in combination with oil palm frond residue mulches against common weeds in landscapes. Sains Malaysiana 48(3): 581-588.

Plimmer, J.R., Gammon, D.W. \& Ragsdale, N.N. 2002. Encyclopedia of Agrochemicals. Vol 1. New Jersey: John Wiley \& Sons, Inc.

Schmitz, G.L., Witt, W.W. \& Mueller, T.C. 2001. The effect of wheat (Triticum aestivum) straw levels on chlorimuron, imazaquin, and imazethapyr dissipation and interception. Weed Technology 15(1): 129-136.

Senseman, S.A. 2007. Herbicide Handbook. USA: Weed Science Society of America.

Shaner, D.L. 2014. Herbicide Handbook. USA: Weed Science Society of America. pp. 335-336.

Sharma, P., Abrol, V. \& Sharma, R. 2011. Impact of tillage and mulch management on economics, energy requirement and crop performance in maize wheat rotation in rainfed subhumid inceptisols, India. European Journal of Agronomy 34(1): 46-51. 
Somireddy, U.R. 2012. Effect of herbicide-organic mulch combinations on weed control and herbicide persistence. Ph.D. The Ohio State University (Unpublished).

Sopena, F., Maqueda, C. \& Morillo, E. 2009. Controlled release formulations of herbicides based on micro-encapsulation. Ciencia e Investigación Agraria 35(1): 27-42.

Taylor, N.G., Laurie, S. \& Turner, S.R. 2000. Multiple cellulose synthase catalytic subunits are required for cellulose synthesis in Arabidopsis. Plant Cell 12(12): 2529-2540.

Dilipkumar Masilamany

Rice Research Center

Malaysian Agricultural Research and Development Institute (MARDI)

13200 Kepala Batas, Pulau Pinang

Malaysia

Muhammad Amirul Nordin

School of Food Science and Technology

Universiti Malaysia Terengganu

20130 Kuala Terengganu, Terengganu Darul Iman

Malaysia
Norhafizah Md Zain

Faculty of Agro-based Industry

Universiti Malaysia Kelantan, Jeli Campus

17600 Jeli, Kelantan Darul Naim

Malaysia

Ismail Bin Sahid

School of Environmental and Natural Resource Sciences

Faculty of Science and Technology

Universiti Kebangsaan Malaysia

43600 UKM Bangi, Selangor Darul Ehsan

Malaysia

Chuah Tse Seng*

Faculty of Plantation and Agrotechnology

Universiti Teknologi MARA

02600 Arau, Perlis Indera Kayangan

Malaysia

*Corresponding author; email: chuahts@uitm.edu.my

Received: 21 February 2020

Accepted: 13 April 2020 